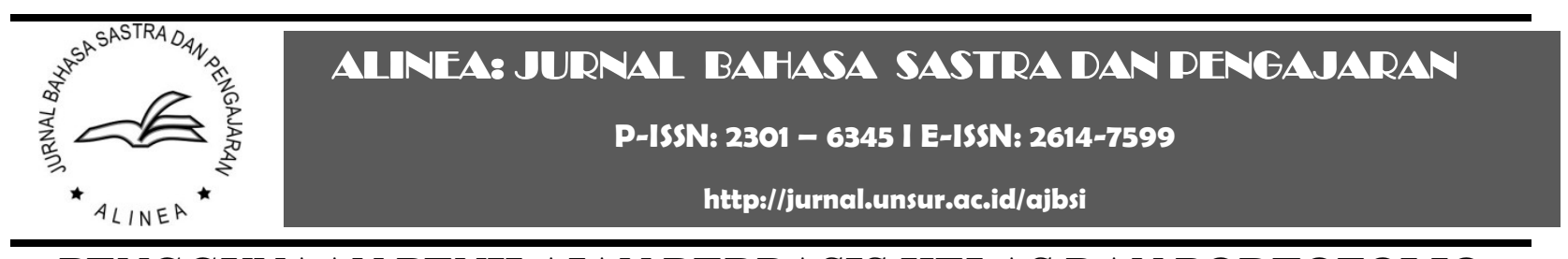

\title{
PENGGUNAAN PENILAIAN BERBASIS KELAS DAN PORTOFOLIO DALAM MENUMBUHKAN MINAT BACA
}

\author{
M. Dian Ferdiana ${ }^{2}$ \& Daud Pamungkas ${ }^{1}$ \\ ${ }^{1}$ SD Al Azhar 18 Cianjur \\ ${ }^{2}$ Universitas Suryakancana, Cianjur
}

Riwayat artikel:

Tiba: 12 April, 2019

Direvisi: 15 Mei, 2019

Diterima: 26 Juni, 2019

Diterbitkan: 30 Oktober, 2019

$\overline{\text { Katakunci: }}$

minat baca

penilaian kelas

portofolio

Alamat surat

daudp@unsur.ac.id

\begin{abstract}
Abstrak:
Artikel ini membahas penggunaan penilaian kelas dan portofolio dalam meningkatkan minat baca. Metode penelitian yang digunakan deskripsi dengan instrumen portofolio, observasi, dan wawancara. Penelitian dilakukan di SD Al Azhar 18 Cianjur, Agustus-Oktober 2018. Portofolio yang digunakan 27 buah yang dibuat oleh anak-anak kelas VI. Selain menggunakan portofolio, data juga diperoleh dari petugas perpustakaan dan guru. Data dalam penelitian adalah judul-judul buku yang dibaca, yang diinginkan dibaca, dan upaya yang dilakukan sekolah dan guru dalam meningkatkan minat baca. Hasil penelitian menunjukkan bahwa minat baca siswa baik. Jumlah rata-rata buku yang dibaca dalam setahun terakhir 6 judul buku yang terdiri dari berbagai buku, tetapi umumnya buku cerita atau cerita. Program pengembangan minat baca yang dilakukan adalah mengunjungi perpustakaan sekolah yang diadakan setiap Senin, 13.00-14.30. Meski begitu, ternyata minat mengunjungi perpustakaan berdasarkan data dua bulan terakhir diketahui tidak terlalu menggembirakan, hanya berjumlah 7,4 siswa yang datang berkunjung dan membaca di perpustakaan.
\end{abstract}

\begin{abstract}
:
This article discusses the use of class and portfolio assessments in developing students' interest in reading. The research method used is description with portfolio instruments, observation, and interviews. The study was conducted at Al Azhar 18 Elementary School in Cianjur, from August to October 2018. Portfolios of twenty seven of $6^{\text {th }}$ grade students were used. In addition to using portfolios, data were also obtained from library staff and teachers. The data in the study were the titles of books read by the students, the titles they wanted, and the efforts made by schools and teachers in increasing reading interest. The results show that students' interest in reading was good. The average number of books read in the past year is 6 titles consisting of various books, commonly story books or stories. The program conducted to develop reading interest is visiting the school library every Monday from 1 to $2.30 \mathrm{pm}$. However, the data taken from the last two months reveal that students' interest in visiting the library is not satisfying, only 7 students came to visit and read in the library
\end{abstract}

\section{PENDAHULUAN}

Sejak adanya perubahan kurikulum dari 1994 menjadi kurikulum 2004, model penilaian yang digunakan adalah penilaian berbasis kelas (classroom-based assessment). Dalam penilaian berbasis kelas, salah satu model atau pendekatan yang digunakan adalah penilaian berbasis portofolio (portofolio-based assessment).

Secara spesifik, penilaian berbasis kelas dapat diartikan sebagai suatu proses pengumpulan, pelaporan, dan penggunaan data dan informasi tentang proses belajar peserta didik untuk menetapkan tingkat pencapaian peserta didik terhadap tujuan pendidikan yang telah 
ditetapkan. Penilaian yang baik ialah penilaian yang mengikuti alur mengumpulkan data, menggodog lebih dahulu secara seksama, kemudian memberikan tafsiran terhadap data yang telah dikumpulkan (Daryanto). Tujuan pendidikan yang dimaksud adalah standar kompetensi, kompetensi dasar, dan indikator pencapaian hasil belajar yang terdapat dalam kurikulum (Arifin).

Sedangkan penilaian portofolio merupakan penilaian berkelanjutan yang didasarkan pada kumpulan informasi yang menunjukan perkembangan kemampuan murid dalam satu periode tertentu. Informasi perkembangan murid tersebut dapat berupa karya murid (hasil pekerjaan, dari proses pembelajaran yang dianggap terbaik oleh muridnya), hasil tes (bukan nilai), piagam penghargaan atau bentuk informasi lain yang terkait dengan kompetensi tertentu dalam satu mata pelajaran (Mulyadi).

Teknik penilaian berbasis kelas, dimaksudkan agar siswa terlibat secara aktif dalam kegiatan pembelajaran, termasuk di dalamnya dalam hal kegiatan pembinaan minat baca siswa. Lebih lanjut dijelaskan bahwa "Penilaian berbasis kelas adalah penilaian dalam arti assesment. Maksudnya, data dan informasi dari penilaian berbasis kelas merupakan salah satu bukti yang dapat digunakan untuk mengukur keberhasilan suatu program pendidikan. Secara spesifik, penilaian berbasis kelas dapat diartikan sebagai suatu proses pengumpulan, pelaporan dan penggunaan data dan informasi tentang hasil belajar peserta didik untuk menetapkan tingkat pencapaian dan penguasaan peserta didik terhadap tujuan pendidikan yang telah ditetapkan" (Baharun).

Dunia pendidikan pada dasarnya tidak bisa lepas dengan yang namanya penilaian karena penilaian menjadi alat ukur untuk mengetahui berhasil atau tidaknya pembelajaran. Akan tetapi, seringkali seorang pendidik hanya menekankan penilaian hasil belajar yang bersifat praktis dan ekonomis saja. Sedangkan penilaian dalam hal proses tidak dilakukan, padahal penilaian proses ini penting.

Selain dikenal istilah penilaian berbasis kelas, dalam bidang penilaian juga dikenal yang namanya portofolio. "Penilaian portofolio digunakan untuk mencapai beberapa tujuan antara lain untuk mengetahui perkembangan yang dialami siswa, untuk mendokumentasikan proses pembelajaran yang berlangsung, memberikan perhatian pada prestasi kerja siswa yang baik, meningkatkan efektivitas proses pembelajaran, bertukar informasi dengan orang tua/wali siswa dan guru lain, dan mempercepat pertumbuhan konsep diri positif pada siswa"(Anugraheni).

Muhana Gipayana dalam penelitiannya membuktikan bahwa konsep kelas yang terpusat pada literasi dan penilaian portofolio layak dinominasikan sebagai konsep unggulan untuk memaksimalkan kualitas pembelajaran (Gipayana). Jika dalam penelitian itu, konsep kelas dan portofolio dterapkan pada pembelajaran menulis, dalam artikel ini kedua konsep itu diterapkan atau dijadikan alat untuk mengukur minat baca siswa sekolah dasar.

Selanjutnya, perlu dikemukakan, bahwa keberhasilan belajar seorang peserta didik dipengaruhi oleh banyak faktor, baik faktor internal maupun eksternal. Faktor internal misalnya motivasi belajar dari peserta didik itu sendiri, sedangkan faktor eksternal misalnya lingkungan dan juga kemampuan professional guru.

Dari uraian tentang portofolio di atas dapat disimpulkan bahwa portofolio memiliki karakteristik sebagai berikut, yaitu (1) merupakan hasil karya siswa yang berisi kemajuan dan penyelesaian tugas-tugas secara terus menerus dalam usaha pencapaian kompetensi pembelajaran, (2) mengukur prestasi siswa secara individual dan menyadari perbedaan di antara siswa, (3) merupakan suatu pendekatan kerjasama, (4) mempunyai tujuan untuk menilai diri sendiri, (5) memperbaiki dan mengupayakan prestasi, dan 
(6) adanya keterkaitan antara penilaian dan pembelajaran (Wasliman).

\section{Tujuan dan Fungsi Penilaian Berbasis Kelas dan Portofolio}

Secara umum semua jenis penilaian berbasis kelas bertujuan untuk menilai hasil belajar peserta didik di sekolah, mempertanggung jawabkan penyelenggaraan pendidikan pada masyarakat, dan untuk mengetahui ketercapaian mutu pendidikan secara umum. Penilaian berbasis kelas bertujuan untuk mengetahui kemajuan dan hasil belajar peserta didik, mendiagnosis kesulitan belajar, memberikan umpan balik/perbaikan proses pembelajaran penentuan kenaikan kelas; dan memotivasi belajar peserta didik dengan cara mengenal dan memahami diri dan merangsang untuk melakukan usaha pendidikan.

Penilaian berbasis kelas berfungsi sebagai bahan pertimbangan dalam menen-tukan kenaikan kelas, umpan balik dalam perbaikan program pengajaran, alat pendorong dalam meningkatkan kemampuan peserta didik, dan sebagai alat untuk peserta didik melakukan evaluasi terhadap kinerjanya peserta bercermin diri (introspeksi diri) misalnya melalui portofolio. Penilaian juga berfungsi sebagai sarana untuk membantu pertumbuhan dan perkembangan pesrta didik secara maksimal. Dengan kata lain penilaian tidak hanya merupakan suatu proses untuk mengklasifikasi kan keberhasilan dan kegagalan dalam belajar (Purwanto).

Pada hakikatnya tujuan penilaian portofolio adalah untuk memberikan informasi kepada orang tua tentang perkembangan peserta didik secara lengkap dengan dukungan data dan dokumen yang akurat. Rapor merupakan bentuk laporan prestasi peserta didik dalam belajar dalam kurun waktu tertentu, sedangkan portofolio dapat dipandang sebagai lampiran dari rapor. Dengan demikian rapor tetap perlu dibuat.
Tujuan portofolio ditentukan oleh apa yang perlu dikerjakan dan siapa yang akan menggunakan penilaian tersebut. Oleh karena itu tidak aneh jika dalam portofolio terdapat tes tertulis (paper and pencil test), project, product, dan catatan kemampuan (records of performance). Lebih lanjut, S. Suropranata dan M. Hatta (Surapranata) mengemukakan penilaian portofolio dapat digunakan untuk mencapai beberapa tujuan, yaitu "menghargai perkembangan yang dialami peserta didik, mendoku-mentasikan proser pembelajaran yang berlangsung, memberi perhatian kepada prestasi kerja peserta didik yang terbaik, merefleksikan kesanggupan mengambil risiko dan melakukan experimentasi, meningkatkan efektivitas proses pengajaran, bertukar informasi dengan orang tua/wali peserta didik dan guru lain, membina dan mempercepat pertumbuhan konsep diri positif pada peserta didik, meningkatkan kemampuan melakukan kemampuan refleksi diri, membantu peserta didik dalam merumuskan tujuan.

Selain itu, portofolio juga bertujuan untuk meningkatkan kerjasama dan pemahaman antara orang tua dan guru, meningkatkan keterlibatan keluarga, menyesuaikan pengalaman keluarga untuk membantu setiap anak tumbuh dengan kecepatannya sendiri, mendorong pengembangan profesi guru dan memungkinkan guru menetapkan kecepatannya sendiri serta memudahkan guru melacak hasil kerya anak pada semua bidang pelajaran (Elizabeth).

Penilaian yang sedang berkembang saat ini adalah penilaian portofolio yang disinyalir memiliki banyak manfaat baik bagi guru maupun bagi siswa. Penilaian portofolio lebih luas dibandingkan penilaian melalui tes, karena dengan portofolio, guru dapat mengikuti perkembangan kognitif, sikap, minat dan berbagai kegiatan siswa (Santoso). Selain itu, penilaian portofolio juga ternyata dapat meningkatkan minat (Madyarini and Gafur) 
dan aktivitas siswa dalam pembelajaran (Nurbaity et al.)

Selanjutnya, dijelaskan bahwa fungsi penilaian portofolio dibagi dalam berbagai segi:

1. Portofolio sebagai sumber informasi bagi guru dan orangtua untuk mengetahui perkembangan dan kemampuan peserta didik, tanggung jawab dalam belajar, perluasan dimensi belajar, dan inovasi pembelajaran.

2. Portofolio sebagai alat pembelajaran merupakan komponen kurikulum, karena portofolio mengperlu kan peserta didik untuk mengoleksi dan menunjukan hasil kerja mereka.

3. Portofolio sebagai alat penilaian autentik (authentic assessment).

4. Portofolio sebagai sumber informasi bagi peserta didik untuk melakukan selfassessment. Dengan demikian peserta didik memiliki waktu yang banyak untuk menilai diri sendiri dari waktu ke waktu.

\section{Prinsip Penilaian Berbasis Kelas}

Pusat kurikulum Balitbang Depdiknas (2002) menjelaskan bahwa secara umum, penilaian berbasis kelas perlu memenuhi prinsip-prinsip: valid, mendidik, berorientasi pada kompetensi, adil dan objektif, terbuka, berkesinambungan, menyeluruh dan bermakna.

\section{Valid (tepat)}

Prinsip ini, mengandung maksud bahwa alat ukur yang digunakan perlu mengukur apa yang akan diukur. Oleh karena itu, agar prinsip ini dapat dijadikan acuan, proses dan hasil penilaian berbasis kelas perlu relevan dan berorientasi pada upaya pencapaian kompetensi dan hasil belajar peserta didik.

\section{Mendidik}

Di sini guru perlu memberikan penghargaan, motivasi dan upaya-upaya mendidik lainnya kepada peserta didik yang berhasil serta membangkitkan semangat peserta didik yang kurang berhasil.

\section{Berorientasi pada kompetensi}

Penilaian berbasis kelas perlu dilakukan dalam membantu peserta didik mencapai standar kompetensi, kompetensi dasar, dan indikator pencapaian hasil belajar yang telah ditentukan. Untuk itu, pendekatan, teknik, model, bentuk, dan format penilaian perlu berorientasi pada kompetensi.

\section{Adil dan objektif}

Guru hendaknya tidak membedabedakan peserta didik atau terpengaruh oleh latar belakang sosial ekonomi, jenis kelamin, budaya, status social, dan etnis peserta didik. Oleh sebab itu, guru perlu membuat perencanaan penilaian yang jelas, komprehensif dan operasional, serta menetapkan kriteria dalam membuat keputusan.

\section{Terbuka}

Sistem dan hasil penilaian berbasis kelas hendaknya tidak disembunyikan atau dirahasiakan. Apapun format dan model penilaiannya, perlu diketahui oleh semua termasuk kriteria dalam menentukan keputusan.

\section{Berkesinambungan}

Penilaian berbasis kelas tidak hanya dilakukan pada akhir kegiatan pembelajaran, tetapi perlu dimulai dari awal sampai akhir pembelajaran, terencana, bertahap, dan berkesinambungan. Hasil penilaian kemudian dianalisis dan ditindaklanjuti sebagai bagian yang terpadu dari proses pembelajaran.

\section{Menyeluruh}

Penilaian terhadap proses dan hasil belajar perlu dilakukan secara menyeluruh, utuh, dan tuntas, baik yang berkenaan dengan domain kognitif, afektif maupun psikomotor. Guru perlu menggunakan berbagai jenis penilaian berbasis kelas sesuai dengan kom-petensi 
yang perlu dikuasai oleh peserta didik seperti penilaian tertulis, penilaian proyek, penilaian penampilan, penilaian portofolio, dsb.

\section{Bermakna}

Penilaian perlu memberikan makna pada berbagai pihak sekaligus untuk melihat tingkat perkembangan penguasaan kompetensi peserta didik sehingga hasil penilaian dapat ditindaklanjuti, oleh guru, orang tua, dan peserta didik.

Sedangkan menurut Direktorat PLP Ditjen Dikdasmen Depdiknas (2003), pelaksanaan penilaian portofolio hendaknya memperhatikan prinsip-prinsip mutual trust, confidentiality, joint ownership, satisfaction, and relevance.

Mutual trust (saling mempercayai), artinya jangan ada saling mencurigai antara guru dengan peserta didik maupun antarpeserta didik.

Confidentiality (kerahasiaan bersama), artinya guru perlu menjaga kerahasiaan semua hasil pekerjaan peserta didik dan dokumen yang ada, baik perseorangan maupun kelompok, tidak boleh diberikan atau diperlihatkan kepada siapapun sebelum diadakan pameran.

Joint ownership (milik bersama), artinya semua hasil pekerjaan peserta didik dan dokumen yang ada perlu menjadi milik bersama antara guru dan peserta didik karena itu perlu dijaga bersama, baik penyimpanannya maupun penempatannya.

Satisfaction (kepuasan), artinya semua dokumen dalam rangka pencapaian standar kompetensi, kompetensi dasar, dan indicator perlu memuaskan semua pihak, baik guru, orang tua, maupun peserta didik.

Relevance (kesesuaian), artinya dokumen yang ada perlu sesuai dengan standar kompetensi, kompetensi dasar, indikator yang diharapkan (Arifin).

\section{Jenis-jenis Penilaian Berbasis Kelas dan Portofolio}

Sumarna Supranata dan Muhammad Hatta (2004) mengemukakan jenis-jenis penilaian berbasis kelas yaitu:

1. Tes Tertulis, yaitu alat penilaian berbasis kelas yang penyajian maupun penggunaannya dalam bentuk tertulis.

2. Tes Perbuatan, tes yang dilakukan pada saat proses pembelajaran berlangsung dan memungkinkan terjadinya praktik.

3. Pemberian Tugas, dapat dilakukan pada semua mata pelajaran mulai dari awal sampai dengan akhir sesuai dengan materi pelajaran dan perkembangan peserta didik.

4. Penilaian Proyek, yaitu penilaian terhadap tugas yang diselesaikan dalam waktu tertentu.

5. Penilaian Produk, yaitu penilaian terhadap penguasaan keterampilan peserta didik dalam membuat suatu produk dan penilaian kualitas hasil kerja tertentu.

6. Penilaian Sikap, yaitu yang berkaitan dengan sikap, seperti sikap terhadap mata pelajaran, sikap terhadap guru, sikap terhadap proses pembelajaran,dll.

7. Penilaian Portofolio, yaitu penilaian berbasis kelas terhadap sekumpulan karya peserta didik yang tersusun secara sistematis dan terorganisasi yang diambil selama proses pembelajaran dalam kurun waktu tertentu (Arifin).

\section{METODE}

Pendekatan yang digunakan dalam penelitian adalah pendekatan kualitatif. Di dalam pendekatan tersebut, terdapat peneli-tian deskriptif yang memiliki data berupa kata-kata atau gambaran sesuatu. Deskripsi merupakan gambaran ciri-ciri data secara akurat sesuai dengan sifat alamiah itu sendiri. Dalam penelitian, data yang dianalisis, yaitu semua informasi yang berkaitan dengan upaya pembinan minat baca atau hasil kegiatan membaca.

Pengumpulan data dilakukan dengan menggunakan dua instrumen, yaitu peneliti 
sebagai instrumen utama dan dokumen portofolio. Penggunaan peneliti sebagai instrumen diguanakan manakala tidak adanya kemungkinan memakai alat lain selain manusia (Djajasudarma).

Data yang dikumpulkan berupa jenis kegiatan pembinaan minat baca, judul-judul buku yang dibaca, serta nama penulis buku yang pernah atau sangat ingin membacanya. Selanjutnya, data tersebut dikumpulkan dengan menggunakan angket dan diidentifikasi dengan teknik baca dan catat.

Selain itu, untuk melengkapi atau memverifikasi data yang ada, dilakukan dengan teknik observasi atau wawancara. Observasi dilakukan untuk melihat aktivitas membaca responden, misalnya kegiatan membaca dan atau mencari bacaan di perpustakaan, sedangkan wawancara dilakukan untuk mengetahui bagaimana kebiasaan baca mereka, upaya apa yang dilakukan dalam menumbuhkan minat baca, serta bagaimana langkah dan cara memberikan penghargaan kepada mereka yang dianggap baik minat bacanya.

Penelitian dilakukan di SD Al Azhar 18 Cianjur pada bulan Agustus-Oktober 2018. Sumber data terdiri atas 27 portofolio yang dibuat oleh anak-anak kelas VI C, terdiri dari 13 perempuan dan 14 laki-laki. Selain itu, data juga diperoleh dari seorang petugas perpustakaan dan seorang guru kelas. Dengan kata lain, yang menjadi objek dalam penelitian berasal dari 27 responden,

Keabsahan data dalam penelitian dilakukan dengan dua konsep, yaitu konsep kesahihan (validitas) dan keterandalan (reliabilitas). Dalam penelitian, digunakan validitas semantik dan reliabilitas melalui cara baca dan kaji ulang. Untuk memperoleh data yang terpercaya, dilakukan tiga cara, yaitu ketekunan pengamatan, triangulasi, dan pengecekan teman sejawat.
Teknik analisis data dalam penelitian berupa teknik kajian isi (content analysis). Definisi kajian isi adalah teknik penelitian yang dimanfaatkan untuk menarik kesimpulan yang replikatif dan sahih dari data atas dasar konteksnya (Krippendorf, 1980: 21). Langkah selanjutnya, dilakukan penyusunan dan kategorisasi. Data yang terkumpul kemudian dipilah-pilah dan dikategorisasikan.

\section{HASIL DAN PEMBAHASAN}

Pada bagian ini akan dipaparkan juduljudul buku yang pernah dibaca, terutama pada satu tahu terakhir, judul-judul buku yang sangat ingin dibaca, buku-buku yang dibaca oleh lebih dari seorang, dan kegiatan-kegiatan yang menunjang pembinaan minat baca yang dilakukan di SD Islam Al Azhar 18 Cianjur.

\section{Buku-Buku yang Dibaca.}

Dari dua puluh tujuh responden terungkap bahwa mereka memiliki pengalaman baca yang beragam dan secara umum mereka memiliki pengalaman baca yang baik. Artinya, ketika diminta menyebutkan juduljudul buku yang pernah dibaca, terutama pada satu tahun terakhir, responden masih bisa mengingat judul-judul buku yang pernah dibaca, bahkan mereka juga masih ingat siapa penulis buku yang pernah mereka baca, atau apa nama penerbit buku yang pernah mereka baca.

Judul-judul buku yang pernah dibaca pada satu tahun terakhir, tetapi tidak mustahil judul-judul buku itu sebenarnya yang bisa mereka ingat saja meskipun boleh jadi dibacanya tidak pada tahun terakhir. Beberapa judul buku yang pernah mereka baca berikut sebagian disajikan secara kelompok berdasarkan aplfabet, atau dimulai dengan judul buku yang diawali dengan huruf $a$ atau angka 1 , kemudian $b, c$, dan seterusnya. Akan tetapi, jika secara teknis diperlukan ada juga yang gabungan beberapa judul buku. 
Buku-buku itu adalah 1 Detik, karya Agus \& Ika Dwi; $100 \%$ Official, karya Aku, karya Naura; Abadurahman, karya Rina Novia; Abaraham Lincoln, karya Nam Kil Kim; Abu Bakar as Siddiq, karya Samih Athif; Adu Jangkrik, karya Adinata; Aku Ingin Jadi Pemain Bola, karya Ira Latief; Aku Naura $100 \%$, terbitan Official Big Rate, Always in My Heart, terbitan Mizan;Amazing Trip, karya Bilqis Mareko Wiharko; Anak Berbakat, karya Ali Syulaim; Anak-Anak di Sekeling Rosululloh, karya Anugrah; dan A-Rubayy binti Awwidz, karya Rini Novie.

Selanjutnya, buku Batu Tua Angker, karya Fatimah; Berani karena Benar, karya Dewi; Berlibur ke Rumah Nenek, karya Sherina; Bersuci, karya Idris Sardi; Bilal dan Hilal, karya Fatharani Yasmin; Bisikan Caroline, karya Yasmin Auralia; Blue Jeans, karya Jahara Revira; Bola Keramat, karya Sabrina Ismail; Boros, karya Azzahra dan Indha; Bts Diary, terbitan Indonesia Army; dan buku Buble World, karya Billy Briliant.

Kemdudian, buku Cintaku: Nelfi, Fajar, Faizah, Dianara, karya Mustafa; Conan, karya Aoyama Gosha; dan buku Cup Cake untuk Bunda, karya Citra dan Rendra.

Berikut buku Dewi Sartika, karya Rima; Diary of March 2, karya Fransisca Intan; Diary of March 3, karya Fransisca Intan; Dillan 1990, karya Nindi Kusuma; Disneyland, karya Firda dan Fia; dan buku Dream to Paris, karya Abida.

Selanjutnya, buku Eifel Cooking Battle, karya Zakia; Eye Cannnoy, karya Rony Ramdani. Kemduian, buku Food Ress Cup Champions, karya Daffa; dan buku Funny Hamster, karya Annisa Vinsa.

Kemudian, buku Ghost Dormitory, karya Fransisca Intan; Gia the Diary of Little Angel, karya Irmna Irawan; Girl Ency-clopaedia Good Friend, Sciences Quiz Terhebat \&
Terdahsyat; Gohst School Day: "C,est La Vie a Paris", karya Romy Hernadi; Gohst School Day "Bintang Medsos", karya Ftaresya Kartika Aratna; Gohst School Day "Drama Quens", karya Romy Hernadi; Gohst School Day "Tas Impian", karya Bambang Irwanto; Gohst School Day: "Rockstar Wannabe", karya Romy Hernadi; Gosht Dormitory, karya Sucia Ramadhani; dan buku Gosht Whisper, karya Rani Rahmawati.

Selanjutnya, buku Hae Yeppo, terbitan Mizan; Hantu di Sekolah Billy, terbitan Media; Hasan dan Husen, karya Rina Novia; Hatihati dengan Langkahmu, karya Dian

Kristian; Hijaber Tomboy, karya Salsabil dan Arsi; dan buku How to Survive, terbitan Princess Etiquete.

Kemudian, buku I Have a Dream, karya Silmi Sabilo; I Love You Mam, Misteri Apel Merah, terbitan Mizan; Jebakan Kucing, karya Rendra M. Ridwan; Juara Sejati, karya Silmi \& Dhanes; Jun dan Dunia Platasium, karya Arinna Jannah; Kampiun Balap Karung, karya Zainal Radar; Kasih Ibu, karya Meols Mulyana; Kasih Sayang Ibu, karya Kak Imat; Keajaiban Senyuman, karya Sri Widiyastuti; Kera Tamak \& Kacrit; Kesebelasan Gen Halilintar, karya Gen Halilintar; Khansa Ibunda Para Syuhada, karya Kak Nostalgiawan; Kisah Bocah-bocah Ajaib, karya Muffin Grafik; KKPK Barang Bekas, karya Naima Ramadhina; KKPK Bea Siswa ke Jepang, karya Siti Rizkia; KKPK Bertualang di Ruang Angkasa, karya Nana Athasa; KKPK I Like Ice Cream, karya Zalza Prabudita; KKPK Lukisan Dudia Bunga, karya Ghaniyah Naira; KKPK Pantai Seribu Kerang, karya Khairunnisa; KKPK Pencuri Permata, karya Mylsha Alea Ramadhani; KKPK Sqlihy Idaman, karya Alit Ahmad; KKPK Tas Baru, karya Rizki Salsabila; Komik Candy POP, karya Kyoko Mizuki \& Yumiko Igarashi; Komik Membantu Ibu Memasak, karya Haedlim \& Kim Soek Hee; KPCI Aku Datang, 
karya Ifa; dan buku Little Princess, karya Anindya dan Tita.

Selanjutnya, buku Made in Emak, karya Arsya \& Indha; Magical Princess, karya Afina dan Friska; Maktuo, karya Sherina Salsabila; Masak Bareng Mama, karya Meols Mulyana; Mengapa Aku Peduli pada Bumi, karya Susan Meredith; Misteri Rawakalong, karya Bambang Joko Susilo; Mom Birthday, karya Aris; Monster University, karya Adinata; dan buku Mudik Adventure, karya Faisal AS.

Kemudian, buku, Nabi Daud, karya Iwan Yuswandi; Nabi Ibrahim, karya Tya Arini; Nabi Muhammad SAW, karya Abdullah Aidi; Namaku Ipung, karya Raditya F.; Naura and the Gank, karya Aku Naura; Novel Boneka Hantu, karya Gary Douberman \& Annable; Of the Record, karya Ria SW; Pandora, karya Utari Rachma Sisi; Pencuri yang Alim, terbitan Mizan; Penguin Ingin Terbang, karya Tevi Hanafi; Pentas Seni di Sekolah, karya Arleen Amijoyo; Peri Biru Unyu-Unyu, karya Ikhtiana; Peri Tersem-bunyi, karya Yosiemeta \& Rini; Pesan Burung Merpati, karya Fadilah Dedi; dan buku Pixi: Lau, Cuaca, Tata Surya, Laut Dalam, Anak Binatang; Pramuka Pramuka Kece, karya Najwa; Quins School, karya Yamsina \& Rendra.

Selanjutnya, buku Reflection, karya Genta Ginting; Rumah Berhantu, terbitan Mizan; Rumah Kita Semua, karya Dewi Lies; Semut Menolong yang Tersesat, karya Tevi Hanafi; Si Alim Hasan, karya Ekyu; Si Icut, karya Dini Marlina; Siapa Dalangnya, karya Vena; Sombong, karya Haibah Affifah Nadiya; Study Hard, karya Lulu Nabila; Suatu Hari di Sungai Sey, karya Agnes Bemoe; dan buku Survival, karya Kim Young Suk.

Kemudian, buku Teka-Teki Rumah Hantu, karya Muthia \& Aish, Televisi, karya Rasid Akbar; Terlambat Sekolah, karya Ahmad Raihan; Teror Bayangan, karya QS Emmus; Teror Si Belang, karya Muthia Fajar;
Thank You Mom, karya Tazkiya; The Adventure Begins, karya Aku Naura; The Diary of a Wimpy Kids: Kidness my Englsih Class, Kisah Para Syuhada, terbitan Mizan; The Official Scarapbook, karya Aku Naura; The Raper Girl, karya Anjali; Trouble in Paris 3, karya Altafia \& Mei; Vero, karya Nabila Rahman, dan buku Why: Batuan dan Mineral, terbitan Young Sean Cho; dan Why: Gua, karya Woo Lyung Sik.

Mengapa buku-buku tersebut yang mereka baca? Jawaban yang memungkinkan untuk hal itu karena bacaan-bacaan itu sesuai dengan minat mereka, dan faktor minat merupakan salah satu faktor yang mempengaruhi hasil belajar (Ainley et al.).

\section{Buku yang Diinginkan untuk Dibaca}

Berdasarkan portofolio yang ada diketahui terdapat beberapa buku yang diinginkan untuk dibaca, bahkan ada beberapa buku yang sangat diinginkan untuk dibaca. Buku-buku itu adalah, buku 3 Menit Belajar Pengetahuan Umum: Olahraga, karya Kim Seok Ho; buku 9 Pejuang Islam, karya Ummu Akbar; buku Abu Bakar, karya Atit Fajar; buku Aku Anak Kreatif, karya Eviliana Elvisa; buku Aku Anak Berbakat, karya Ali Sulaiman; buku Aku Datang, karya Alifa; buku Anak Muslim (Gaul Kocak ala Islam), karya Aruma; dan buku Asih, karya Risa Saraswati.

Selanjutnya, buku yang diinginkan untuk dibaca adalah buku Bangra's New Manager, karya Bang Mirae; buku Be Your Self, karya Zuhrotun; buku Bintang, karya Tere Liye; buku Bulan, karya Tere Liye; buku Bumi, karya Tere Liye; buku Cave, karya Jeong Soo Eun; buku Color full Rain, karya Jilva \& Yara; dan buku Conan Vol 48, karya Aoyama Gosha. 
Kemudian, buku Dillan 1990, karya Nindi Kusuma; buku Dog Day, Bad Days, Ran Days, karya Ivana Saraswati; buku Food Ress Cup Champions, karya Daffa; buku Gosht Darmitory 2, karya Zarry Hendrik; buku Hai Milko, karya Ono Eriko; buku Hans, karya Risa Saraswati; buku Hati-Hati dengan Kendaraanmu, karya Dian Kristiani; buku Hati-Hati Kita Semua, karya Hany V.; buku Hendrick, karya Risa Saraswati; buku I Wait Mr. Panda, karya Steve Antony; buku Invisible Boy, karya Arif TY Pranata; buku Ivana, karya Risa Saraswati; buku Ivana van Dijk, karya Risa Saraswati; buku Janshen, karya Risa Saraswati; buku Juri Pilihan, karya John Grisham; dan buku Jurnal Maddan, karya Risa Saraswati.

Selanjutnya, buku Kecil-Kecil Punya Karya, karya Salsabila Amanda Dewi; buku Kesebelasan Geng Halilintar, karya Gen Halilintar; buku Ketua Kelas yang Adil, karya Eviliana \& Tsabita el Kansa; buku Kita Semua Sama, karya Mukhtar Selawati; dan buku KKPK Holiday Korea; Komet, karya Tere Liye.

Kemudian, buku Laboratorium Liana, karya Caca; buku Laskar Pelangi, karya Andrea Hirata; buku Matahari, karya Tere Liye; buku Memahami Biologi, karya Hazel Maskeli; buku Menolong yang Tersesat, karya Tefi Hartati; buku Merintih Berang Ivana van Dijk, karya Risa Saraswati; buku Misteri Biola Konser, karya Dewi Liez; buku Misteri Delman Merah Jambu, karya Apriliana Prasasti; buku Misteri Kamar Mandi, karya Ivana Saraswati; buku Misteri Konsel Biola, karya Ayesha; buku Misteri Koper Detektif, karya Eisha; buku Misteri Rawakalong, karya Bambang Joko Susilo; dan buku Monster University, karya Stuart Smith.

Kemudian, buku Nabi Muhammad, karya Putri Mokoginta; buku Nabi Yunus, karya Rofiq Arohman; buku Namaku Ipung, karya Joko Susilo; buku Naura and the Gank, karya Aku Naura; buku Off The Record, karya Ria SW.; buku Pandua Hidup Anak, karya Hwang buku Sang Gyu; Peri Biru Unyu-Unyu, karya Sekarnisa; buku Peter, karya Risa Saraswati; buku Petualangan Daren ku, karya Arif Fajar Abadi; buku Pramuka-Pramuka Kece, karya Najwa; buku Putri Kesayangan Ayah, karya Mary Higgins Clark; buku Rana dan Rani, karya Nandya Arsy Khairinnisa; buku Rangking Satu, karya Sara Tee; buku Rasuk, karya Risa Saraswati; buku Risa Saraswati, karya Risa Saraswati; buku Rumah Kita Semua, karya Dewi Liez; buku Samantha, karya Risa Saraswati; buku Si Deong, karya Agung Gunawan; buku Si Juki, karya Faza Ibnu Ubaidilah; buku Silam, karya Risa Saraswati; buku Sistem Syaraf, karya Risa Saraswati; buku Suatu Hari di Sungai Sey, karya Agnes Bemoe; buku Sunyaruti, karya Risa Saraswati; dan buku Survival, karya Kim Young Suk.

Selanjutnya, buku Ten Ten Series: Dewasa, karya Kim G. Yeong Ah; buku Ten Ten Series: English Words, karya Hwang Eung Young; buku Ten Ten Series: Smart Study, karya GI Songi; buku Tendangan Lintang, karya Hikmah Sujana; buku Tentang Perkara Paling Najis Sedunia, karya Dewi; buku The Adventure Begins, karya Aku Naura; buku The Diary of Wimpy Kids, karya Rodric Rule; buku The Offocial Scrapbook; Thomas Alfa Edison; Timun Emas, karya Bang V; buku Why, karya Endah Nawang; buku William, karya Risa Saraswati; dan buku With Princess Issabel Ever Say Please, karya Steve Metzger

\section{Buku-buku yang Populer}

Dari sejumlah buku seperti yang sudah dikemukakan, ada beberapa buku yang dapat dikategorikan buku populer dilakalang pembaca yang menjadi responden. Buku populer itu merupakan buku yang pembacanya lebih dari seorang, artinya misalnya buku A diaca oleh dua orang bahkan lebih. 
Berikut disajikan secara berurutan mulai bulu yang paling populer dengan pemnaca terbanyak, yaitu buku Penguin Ingin Terbang, karya Tevi Hanafi (dibaca oleh 9 pembaca), buku Suatu Hari di Sungai Sey, karya Agnes Bemoe (dibaca oleh 4 pembaca), buku Abaraham Lincoln, karya Nam Kil Kim, buku Adu Jangkrik, karya Adinata, buku Berlibur ke Rumah Nenek, karya Sherina, buku Made in Emak, karya Arsya \& Indha (masing-masing dibaca oleh 3 pembaca).

Kemudian, buku Abu Bakar as Siddiq, karya Samih Athif, buku Bersuci, karya Idris Sardi, buku Blue Jeans, karya Jahara Revira, buku Cup Cake untuk Bunda, karya Citra dan Rendra, dan buku Dewi Sartika, karya Rima, buku Gia the Diary of Little Angel, karya Irmna Irawan, buku Little Princess, karya Anindya dan Tita, buku Magical Princess, karya Afina dan Friska, buku Misteri Rawakalong, karya Bambang Joko Susilo, buku Nabi Muhammad SAW, karya Abdullah Aidi, buku Pentas Seni di Sekolah, karya Arleen Amijoyo, dan buku Teror Bayangan, karya QS Emmusm (masing-masing dibaca oleh 2 pembaca)

\section{Kegiatan-kegiatan Pembinaan Minat Baca}

Beberapa upaya yang dilakukan guru dan pihak sekolah dalam rangka meningkatkan minat baca siswa antara lain menyediakan buku-buku bacaan di perpustakaan sekolah, mengadakan jam wajib baca di perpustakaan secara periodik, dan memberikan penghargaan kepada siswa yang rajin membaca.

Perpustakaan, yang dikenal PSB terletak di lanti III gedung SD Al Azhar 18 Cianjur. Perpustakaan itu terletak di bagian pojok, atas, dengan luas kurang lebih 8 x 8 meter. Di perpustakaan itu selain ada berbagai buku bacaan juga ada berbagai peralatan.
Dari pengamatan pada saat beberapa kali berkunjung ke perpustakaan, buku-buku yang tersedia diperputakaan itu umumnya dapat dikategorikan buku pelajaran, dan sebagian kecil buku umum dan buku cerita, yang mestinya mendominasi buku-buku yang ada di perpustakaan sekolah, lebih-lebih perpustakaan sekolah dasar sebab seperti diketahui minat anak tingkat sekolah dasar terutama pada cerita petualangan, cerita tokoh, dan kisah.

Jam wajib berkunjung sekaligus membaca diperpustakaan, dilakukan secara bergilir, misalnya siswa kelas VI C mendapatkan jadwal berkunjung/membaca di PSB setiap minggu pada hari Senin, pukul 13.00-14.30 Pada saat berkunjung ke PSB siswa diberi kebebasan untuk memili dan membaca buku yang disukainya, seperti tampak pada beberapa foto berikut.

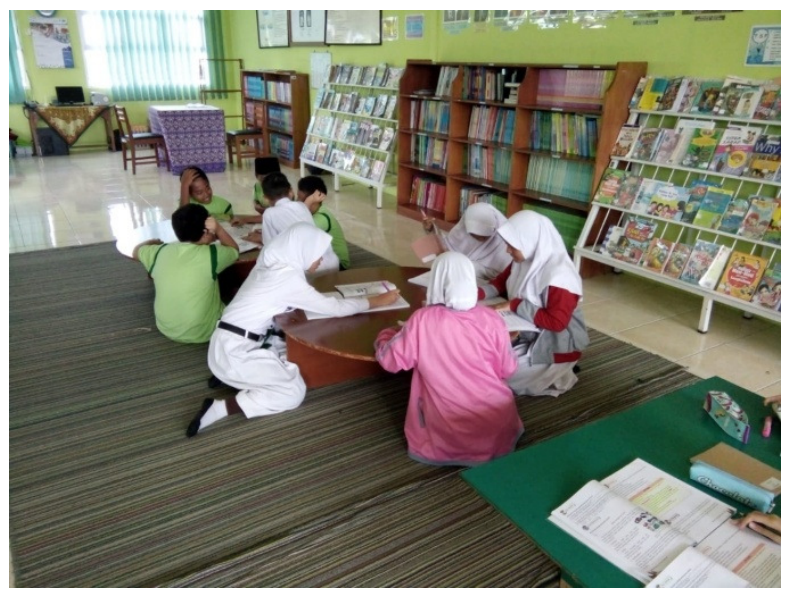

Gambar 1: Siswa sedang membaca pada jadwal mingguan di perpustakaan

Hal yang patut diteladani berkaitan dengan upaya pembinaan minat baca yang dilakukan sekolah adalah kegiatan memberikan pengahargaan kepada siswa yang rajin membaca pada setiap bulan. Dari informasi yang didapat, misalnya pada Juli 2018 yang mendapatkan piagam penghargaan terajin membaca adalah siswa yang bernama Quera Calista, siswa kelas 4 A, sedangkan pada bulan Agustus 2018 siswa terajin membaca 
adalah siswa yang bernama Michele G, siswa kelas 4 A juga, seperti tampak pada gambar berikut.

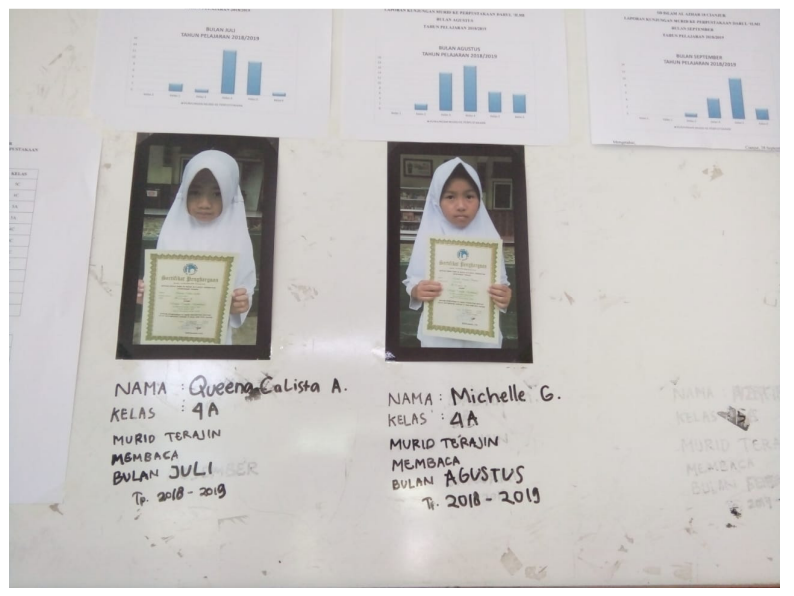

Gambar 2: Siswa yang mendapatkan penghargaan sebagai siswa terajin membaca

\section{PENUTUP}

Penilaian berbasis kelas dan portofolio dapat digunakan untuk mengidentifikasi bagaimana minat baca para siswa di suatu sekolah, termasuk di SD Islam Al Azhar 18 Cianjur. Berkenaan dengan hal itu dalam penelitian dapat diketahui bagaimana pengalaman baca responden melalui judul-judul buku yang pernah mereka baca.

Melalui penilaian berbasis kelas dan portofolio, antara lain dapat diketahui buku apa saja yang pernah dibaca, serta berapa banyak mereka membaca pada periode tertentu, misalnya dalam satu tahun. Selain itu, juga dapat diketahui buku apa saja yang ingin dibaca, bahkan sangat ingin dibaca. Tentu saja informasi seperti itu berguna terutama untuk pihak sekolah pada saat akan mengembangkan atau melakukan pengadaan bahan baca atau buku-buku koleksi perpustakaan. Hal itu, juga berguna untuk pengembangan pustaka, bahkan bukan hanya menjadi tahu buku-buku yang mereka inginkan bahkan yang sangat mereka inginkan karena ternyata ada beberapa buku yang diminati oleh lebih dari seorang responden.

Buku-buku yang dibaca diketahui bervariasi mulai buku cerita, buku pengetahuan, dan biografi para nabi. Hal itu tampaknya sesuai dengan minat usia perkembangan mereka yang menyukai cerita, pengetahuan, dan kisah totoh terkenal baik tokoh agama mapun tokoh dunia.

Begitu juga buku-buku yang diinginkan untuk dibaca, bervariasi. Jika dicermati bukubuku yang diingankan untuk dibaca sebagian merupakan minat sendiri, tetapi ada juga buku-buku yang pernah dibaca oleh yang lain, dalam hal ini teman sekelas. Dengan demikian, pengaruh teman sekelas dalam meningkatkan minat baca perlu mendapatkan perhatian.

Yang perlu juga dikemukakan bahwa ada sebagian siswa yang memiliki minat atas buku-buku dari penulis tertentu. Hal itu, tampak dari judul-judul buku yang dibaca yang ditulis oleh pengarang yang sama, misalnya ada yang telah membaca berbagai buku dari pengarang yang bernama Risa Saraswati.

Kemudian, dari buku-buku yaang pernah dibaca atau dari buku-buku diinginkan untuk dibaca, secara tersirat tampak bahwa bukubuku anak-anak yang benar-benar Indonesia sangat sedikit. Dari sejumlah judul buku yang muncul, buku-buku anak-anak yang benarbenar Indonesia hanya ada satu dua saja. Artinya, kebanyakan buku anak-anak yang dibaca atau diinginkan untuk dibaca adalah buku-buku luar yang telah dialihbasakan, termasuk buku-buku dari para pengarang Korea. Jadi, budaya K-Pop telah merasuk kepada bangsa kita, tidak hanya dalam bentuk sinetron dan lagu, tetapi juga berupa bukubuku cerita. Ini merupakan sesuatu yang perlu mendapatkan perhatian orang tua, guru, dan pemerintah. 
Tearkhir, hasil penelitian menunjukan bahwa minat baca siswa SD Al Azhar 18 Cianjur tergolong baik. Rata-rata jumlah buku yang dibaca pada satu tahun terahir berjumlah 6 judul buku terdiri dari macam-macam buku, tetapi umumnya buku cerita atau kisah.
Program pembinaan minat baca yang rutin dikerjakan yaitu mengunjungi perpustakaan sekolah yang dilakukan, setiap hari Senin, pada pukul 13.00-14.30, tampaknya masih perlu dipikirkan adalah bagaimana merangsang siswa agar mereka lebih senang berkunjung ke perpustakaan.

\section{DAFTAR PUSTAKA}

Ainley, Mary, et al. "Interest, Learning, and the Psychological Processes That Mediate Their Relationship." Journal of Educational Psychology, 2002, doi:10.1037/0022-0663.94.3.545.

Anugraheni, Indri. "Penggunaan Portofolio dalam Perkuliahan Penilaian Pembelajaran.” Jurnal Pendidikan Dasar PerKhasa, vol. 3, no. 1, 2017, pp. 197-203.

Arifin, Zaenal. Evaluasi Pembelajaran. PT. Remaja Rosda Karya, 2010.

Baharun, Hasan. "Penilaian Berbasis Kelas pada Pembelajaran Pendidikan Agama Islam di Madrasah.” MODELING: Jurnal Program Studi PGMI, vol. 3, no. 2, 2016.

Daryanto. Evaluasi Pendidikan. Adi Mahastya, 2010.

Djajasudarma, T. Fatimah. Metode Linguistik Ancangan Metode Penelitian dan Kajian. PT. Eresco, 2006.

Elizabeth, Cathy Grace. Pintar Membuat Portofolio. Erlangga Group, 2006.

Gipayana, Muhana. "Pengajaran Literasi dan Penilaian Portofolio dalam Konteks Pembelajaran Menulis Di SD.” Jurnal Ilmu Pendidikan, vol. 11, no. 1, 2004, pp. 1-12.

Madyarini, Dyan Desi, and Abdul Gafur. "Komparasi Model Pembelajaran Portofolio dan PBL Terhadap Hasil Belajar IPS di SMPN Kecamatan Sewon.” Harmoni Sosial: Jurnal Pendidikan IPS, 2015, doi:10.21831/hsjpi.v2i2.7664.

Mulyadi. Evaluasi Pendidikan. UIN Maliki Press, 2010.

Nurbaity, et al. "Meningkatkan Aktivitas Belajar Siswa dalam IPA Terpadu Menggunakan Penilaian Portofolio Melalui Lesson Study di SMP Sekolah Alam dan Sains Aljannah Jakarta." Jurnal Pendidikan dan Kebudayaan, 2010.

Purwanto, Ngalim. Evaluasi Pengajaran. PT Remaja Rosda Karya, 2002.

Santoso, Budi. "Penilaian Portofolio dalam Matematika." Jurnal Pendidikan Matematika, vol. 1, no. 2, 2017, pp. 31-38, doi:10.22342/jpm.1.2.811.

Surapranata, Sumarna \&. Muhammad Hatta. Penilaian Portofolio. PT Remaja Rosda Karya, 2007.

Wasliman, Iim \&. Numan Somantri. Portofolio dalam Pembelajaran IPS. PT Remaja Rosda Karya, 2009. 